the Atlantic Ocean H. Forskcalii does not attain so large a size as in the Mediterranean.

Cucumaria Koellikeri, Semp., hitherto known only from Sicily and Naples, has likewise under another name figured for some time past as a member of the Holothurian fauna of the Atlantic. I regard Cucumaria Lefevrii, Th. Barrois (1882), from Concarneau, as the same species, though certainly the figures of the calcareous bodies do not justify this supposition. I have already explained in my memoir on the Holothurians of the 'Hirondelle,' at present in the press, that it is not advisable to follow Hérouard ("Recherches sur les Holothuries des côtes de France," Arch. Zool. Exp. [2] vol. vii. 1890) in regarding Cucumaria Lefevrii, with ten tentacles, as synonymous with Thompson's old species C. Drumondii, which is now assigned to the genus Phyllophorus. Since I have in the meantime learned to know the species, I can now also protest against Hérouard's attempt to regard Thyone gemmata, Pourt., of the American coasts, as of the same value. In the determination of C. Koellikeri, Semp., from Sines, I used an original specimen which belonged to Semper.

Cucumaria Montagui, Flem. (=le Fleurilardé, Dicquemarre, 1778 ; =Colochirus Andersoni, Lampert, 1885 ;=Colochirus Lacazei, Hérouard, 1890), was represented by three quite young specimens measuring from 4 to 8 millim. in length. Jeffrey Bell (loc.cit.) has not recognized this conspicuous species, which also occurs on the coasts of Great Britain. I have set forth its synonymy at length in my memoir alluded to above. The examination of these young specimens has decided me to give a new, and perhaps finally satisfactory solution of the question as to what Forbes ("A History of British Starfishes,' London, 1841) understood by his "Psolinus brevis." The choice of the generic name proves that Forbes wished to draw attention to the contrast between the dorsal and ventral surface, which distantiy recalled Psolus. It is precisely this peculiarity that distinguishes $C$. Montagui, and this it was also that misled Lampert and Hérouard, so as to make them think of Colochirus, since in the species of this genus the feet are confined to the ventral surface. The sole difference between the contracted young specimens of C. Montagui from Sines and the figure of Psolinus brevis drawn from life, consists in the fact that in the former the feet are more numerous and are not arranged in a single row. It is well known that Lütken referred Psolinus brevis to Cucumaria (Ocnus) minuta, F.-Sitzgs.-Ber. k. Akad. Wiss. Wien, math.naturw. Classe, Jahrg. 1893, no. xii. pp. 107-109.

On the Habits of Blennius sphynx, Cuv. \& Val., and of Blennius Montagui, Fleming. By M. Frédéric GuIteL*.

The construction of the great experimental fish-pond, recently added to the laboratory at Banyuls-sur-Mer, has enabled me to make certain observations which I had vainly endeavoured to carry out

* The observations here described were made at the zoological laboratory at Banyuls-sur-Mer (Pyrénées Orientales). 
successfully hitherto. A large number of littoral animals, finding in this pool a safe shelter from the rough sea, have come to choose their abode in it ; they are found there under conditions exceptionally favourable for uninterrupted observation. Blennius sphynx is a case in point. Many individuals belonging to this pretty species have made their way into the basin in order to construct their nests in it. Some have chosen the holes with which the schist forming the sides is pierced in all directions; others have established themselves in the tunnels bored by the Teredos in the timbers which have been utilized for the construction of the coffer-dams.

The male of Blennius sphynx selects as the locality of his nest a little cavity with a narrow opening, just large enough to allow his body to pass through. His pretty head, which is black striped with blue, and surmounted by two graceful yellow horns, alone projects from the hole, and the little creature remains constantly on the watch in this position; as soon as he espies a female searching for food among the surrounding algæ, he raises himself halfway out of the nest, while his spiny dorsal fin, which is greatly elevated and very vividly coloured, assumes a vertical position; he imparts to the anterior portion of his body a vertical swaying motion, undoubtedly with the object of attracting the female. If the latter does not respond to this invitation, the male leaves the nest and goes to meet her. His colours become extremely vivid, and his head suddenly darkens, which again causes the blue streaks with which it is adorned to stand out more sharply; the black, yellow, and blue bands on the sides of his body acquire a brilliancy of striking effect, and he darts suddenly upon the female, at the same time again erecting his magnificent dorsal fin.

These demonstrations do not always succeed in ensuring the success of the little male; but, if his appeals are listened to, the female enters the nest and soon commences to deposit her eggs, which adhere to the walls of the nest by means of delicate filaments of a glutinous nature and follicular origin, attached to the base of the shell around the micropyle. During the whole of the time occupied by the spawning the male is the victim of intense excitement. $\mathrm{He}$ cruises around his hole to keep watch on its approaches; when the female, who is completely hidden within the nest, allows her head to be seen and makes a show of wishing to escape, he flies at her and bites her in order to force her to reenter. From time to time he penetrates into the nest; he is seen to move rapidly and then to undergo a sort of violent shudder, accompanied by a slight forward movement, which corresponds to the emission of the semen destined for the fertilization of the ova which have been deposited.

The scenes which I have just described are repeated until, spawning being completed, the female abandons the nest to return to it no more. The male, who is polygamous, remains as the faithful guardian of the ova deposited by the different females which he receives in his domicile, and acquits himself of his task with surprising perseverance and tenacity.

I have captured males guarding their ova and transported them 
into a tank of the aquarium. When, after the lapse of fourteen and even eight and twenty hours, I have brought them back to within a short distance from their abode, they have always found it again. I have taken a male watching over his offspring and set him at liberty forthwith, at a distance of 12 metres from the floating plank in which he had established his nest; this plank was surrounded by a large number of others, pointing in all directions and immersed at different levels; nevertheless, after a certain time, he was back again at his post. Another male, placed in the same conditions, was transported to a distance of 28 metres from his nest, and returned to it an hour and a half afterwards. A third, in order to return to his ova, was obliged to cross the pool, which is 50 metres wide. These facts, and others besides which I shall shortly publish, indicate in Blennius sphynx a very great development of memory and an attachment to his ova which is quite remarkable.

If sand, gravel, shells, or objects of any kind be introduced into his dwelling or placed so as to block up his door, the male removes them to a distance by carrying them in his mouth.

He always enters his hole backwards, first introducing into it the extremity of his tail, upon which he proceeds to haul by bending it so as to gain a hold upon the walls of his dwelling. He savagely pursues the shrimps, which infallibly devour his ova if he is imprudent enough to leave them too long. He also furiously chases the fish which pass near his hole, especially the other males, and follows and bites them, if they do not flee to a sufficient distance.

To witness a battle it is not necessary to await the advent of another male. As a matter of fact, if we take a mirror and alternately bring it near to and withdraw it from the guardian of a nest, we easily succeed in convincing him that he is attacked by one of his fellows; he then issues from his retreat, and flies at his own image, striking his snout violently against the mirror, and does not cease until his imaginary adversary is withdrawn.

Blennius Montagui is very abundant at Banyuls-sur-Mer. It is easily captured with the hand on searching the clefts of rocks at no great depth, which are clothed with shore sea-weeds. My observations, made in April 1892, were conducted upon specimens living in captivity in a tank of the aquarium at the Arago laboratory.

The male, like that of Blennius sphynx, is alone burdened with the care of the ova. He establishes his nest beneath a stone which is hollowed out on the underside.

When a gravid female passes near his domicile, he darts towards her, agitates his whole body very rapidly in order to attract her attention, and even brushes her with the tip of his snout; if he is unsuccessful he returns to his nest: he constantly raises and lowers the whole anterior portion of his body, and sways at the same time to the right and left; then he returns towards the female, and excites her afresh. If the latter allows herself to be tempted, she enters the nest with him, turns over with her ventral side uppermost, and deposits her ova on the roof of the nest, in a layer which covers a large area of it. 
During this time the male, remaining at her side, leans and rubs himself gently against her; then, all at once, he himself turns over towards the ceiling of the nest, his tail waves with a regular motion, and finally a tremor accompanied by a slight forward movement agitates his whole body. This is recognizable as the genital spasm.

On the conclusion of the spawning, the female abandons the nest while the male remains as the assiduous guardian of it. He keeps his pectoral fins and tail continually in motion to ensure the constant renewal of the water. He furiously pursues the other fish which pass too near him : if one of them, even much larger than himself, happens to penetrate into his nest, he bites and worries it until it takes to flight.

Blennius Montagui is extremely careful as to the cleanliness of his abode; he carries away to a distance all foreign bodies which enter it, driven by the currents. Nothing is so curious as to see him seize with his mouth large fragments of shells, and carry them to the furthest possible distance from his nest. It is impossible to succeed in tiring out his patience; he casts outside his dwelling all foreign bodies introduced by the observer.

The females spawn several times during the same season, and the same male fertilizes the ova of several different females. The male guards his progeny only so long as the incubation of the ova lasts; the embryos on hatching are left to themselves and live in the open water.-Comptes Rendus, t. exvii. no. 5 (July 31, 1893), pp. 289291.

\section{A Synopsis of the European Newts.}

By Dr. J. von Bedriaga, of Nice.

Since the publication of my detailed treatise upon the Urodele Amphibia of Europe will still take some time, I venture to bring forward at once a systematic arrangement of our species of Molge. In so doing it is my intention to lay stress chiefly upon permanent differences, and I shall endeavour to disregard secondary sexual characters.

Several years ago Leydig and later Boulenger alluded to constant specific characters in the case of certain Urodela. Nevertheless batrachologists do not yet seem to have succeeded in discovering in the case of all our species of newts characters which are at all times recognizable and common to both sexes, since in all analytical tables we are invariably confronted with the time-honoured enumeration of secondary sexual characters, as well as of sexual peculiarities which are subject to periodical changes. Moreover, owing to the fact that features belonging to the last-mentioned category occur more especially in the male sex, we acquire in the majority of cases no conception of the specific type, but rather obtain a complex of characters which merely serves for the definite determination of the male individuals. The characteristics upon which an empirical distinction of the females was based had, as is well known, in many cases to be sought in the coloration, size, and shape of the entire 


\section{$2 \mathrm{BHL}$ Biodiversity Heritage Library}

Guitel, Frédéric Sylvain. 1893. "On the habits of Blennius sphynx, Cuv. \& Val., and of Blennius Montagui, Fleming." The Annals and magazine of natural history; zoology, botany, and geology 12, 335-338.

https://doi.org/10.1080/00222939308677631.

View This Item Online: https://www.biodiversitylibrary.org/item/78509

DOI: https://doi.org/10.1080/00222939308677631

Permalink: https://www.biodiversitylibrary.org/partpdf/62303

\section{Holding Institution}

University of Toronto - Gerstein Science Information Centre

\section{Sponsored by}

University of Toronto

\section{Copyright \& Reuse}

Copyright Status: NOT_IN_COPYRIGHT

This document was created from content at the Biodiversity Heritage Library, the world's largest open access digital library for biodiversity literature and archives. Visit BHL at https://www.biodiversitylibrary.org. 